\title{
Evaluation of cyclooxygenase-2 inhibition in an orthotopic murine model of lung cancer for dose-dependent effect
}

\author{
Eric M. Sievers, MD, Robert D. Bart, MD, ${ }^{*}$ Leah M. Backhus, MD, Yuanguang Lin, MD, Margaret Starnes, BA, \\ Roberto Castanos, BS, Vaughn A. Starnes, MD, and Ross. M. Bremner, MD, PhD*
}

From the Department of Cardiothoracic Surgery, University of Southern California, Keck School of Medicine, the Hastings Thoracic Oncology Laboratory, Los Angeles, Calif.

Funded by the Robert E. Gross Research Scholarship and the Hastings Foundation.

Read at the Thirtieth Annual Meeting of The Western Thoracic Surgical Association, Maui, Hawaii, June 23-26, 2004.

Received for publication July 5, 2004; revisions received Dec 8, 2004; accepted for publication Dec 20, 2004

Address for reprints: Ross M. Bremner, MD, $\mathrm{PhD}$, Department of Cardiothoracic Surgery, Keck School of Medicine, 1520 San Pablo St, Suite 4300, Los Angeles, CA 90033 (E-mail: rbremner@surgery.usc.edu)

*Co-directors of the Hastings Thoracic Oncology Laboratory at the University of Southern California Keck School of Medicine.

J Thorac Cardiovasc Surg 2005;129:1242-9

$0022-5223 / \$ 30.00$

Copyright (c) 2005 by The American Association for Thoracic Surgery

doi:10.1016/j.jtcvs.2004.12.048
Objectives: Cyclooxygenase- 2 plays a role in growth, apoptosis, angiogenesis, and metastasis in lung cancer. Inhibition of cyclooxygenase- 2 with celecoxib has been shown to inhibit tumor growth. We evaluated the effect of increasing doses of celecoxib in a murine model of human lung cancer.

Methods: Human lung adenocarcinoma cells (A549) were implanted in the left lung upper lobe of mice with severe combined immunodeficiency syndrome. Mice were randomly assigned to 4 groups at implantation ( $\mathrm{n}=10$ per group): control, $125 \mathrm{mg} / \mathrm{kg}$ chow, $500 \mathrm{mg} / \mathrm{kg}$ chow, $1000 \mathrm{mg} / \mathrm{kg}$ chow. After 3 weeks, mice were killed, and a blinded observer measured total tumor volume. The dose effect of celecoxib was examined in vitro by studying cell proliferation, expression of cyclooxygenase-2 (mRNA and protein), and production of prostaglandin $\mathrm{E}_{2}$ in unstimulated and interleukin $1 \beta$-stimulated cells.

Results: All 40 mice survived for 3 weeks with no observed toxicities. Total tumor volume was inhibited in each celecoxib group $(P=.0038$, Welch analysis of variance): $206.7 \pm 119.5 \mathrm{~mm}^{3}$ (control group), $41.4 \pm 54.0 \mathrm{~mm}^{3}$ (low-dose group), $34.5 \pm 39.3 \mathrm{~mm}^{3}$ (medium-dose group), and $27.3 \pm 53.6 \mathrm{~mm}^{3}$ (high-dose group). In vitro celecoxib was effective at inhibiting production of prostaglandin $E_{2}$, even in stimulated cells, although little effect was seen on cyclooxygenase- 2 protein levels. Inhibition of proliferation was evident only at doses that exceeded those used in the animal model.

Conclusion: Inhibition of cyclooxygenase- 2 with low-dose celecoxib restricted the growth of lung cancer in this model. This might be mediated by prostaglandin $\mathrm{E}_{2}$. Higher doses of celecoxib afforded no additional benefit. Chronic therapy with low-dose cyclooxygenase- 2 inhibition has the potential to influence tumor progression in non-small cell lung cancer.

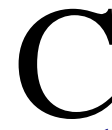
yclooxygenase-2 (COX-2) has been implicated as an important factor in many epithelial tumors, including non-small cell lung cancer (NSCLC), in which expression of the enzyme is present in more than $70 \%$ of cases. ${ }^{1-5}$ Cox-2 has been shown to affect many aspects of tumor development, including angiogenesis, growth, invasion, and apoptosis. ${ }^{6-8}$ In addition, COX-2 is thought to promote metastatic behavior, although the mechanisms responsible are not defined. ${ }^{9}$

We have previously shown that selective COX-2 inhibition with celecoxib markedly decreased tumor growth and mediastinal metastases of a human lung cancer cell line in an orthotopic mouse model. ${ }^{10}$ Evidence from other in vivo models with lung cancer cell lines suggests that higher doses of celecoxib further suppress tumors. ${ }^{11-14}$ This study was performed to assess whether selective COX-2 inhibition has a dose-dependent effect on orthotopic NSCLC tumor growth by use of a well-studied lung adenocarcinoma cell line, A549. 


\section{Methods}

The University of Southern California Institutional Animal Care and Use Committee approved this animal study. All animals received humane care in compliance with the "Guide for the Care and Use of Laboratory Animals" published by the National Institutes of Health.

\section{Cell Culture}

Cells of the human lung adenocarcinoma cell line A549 (American Type Culture Collection, Manassas, Va) were cultured in RPMI-1640 supplemented with $5 \%$ fetal bovine serum (GIBCO, Carlsbad, Calif), $2 \mathrm{mmol} / \mathrm{L}$ glutamine, $100 \mathrm{U} / \mathrm{mL}$ penicillin, and $100 \mu \mathrm{g} / \mathrm{mL}$ streptomycin at $37^{\circ} \mathrm{C}$ in a $5 \% \mathrm{CO}_{2}$ humidified atmosphere. Cells were grown to confluence and prepared for the following experiments.

In vivo model. Six-week old mice with severe combined immunodeficiency syndrome (SCID-bg male mice; Harlan Sprague Dawley, Inc, Indianapolis, Ind) were housed in polycarbonate cages ( 5 per cage) in a room lit for 12 hours each day and maintained at $27^{\circ} \mathrm{C}$ for 2 days before injection. Teklad (4\%) diet (Harlan Teklad, Madison, Wis) and tap water were provided ad libitum. Treatment diet consisted of Teklad (4\%) mixed with celecoxib at $125 \mathrm{mg} / \mathrm{kg}$ chow (low dose), $500 \mathrm{mg} / \mathrm{kg}$ chow (medium dose), and $1000 \mathrm{mg} / \mathrm{kg}$ chow (high dose). Mice were randomly assigned to 4 groups at implantation $(n=10$ per group): control, low-dose, medium-dose, and high-dose groups. Celecoxib administration began on the day of tumor cell implantation and continued for 21 days.

In preparation for injection, A549 cells were resuspended to a concentration of $2 \times 10^{6}$ cells per $25 \mu \mathrm{L}$ in PBS. Cell viability was greater than $94 \%$ (trypan blue stain) before and after the procedure. Mice were anesthetized by titrating isoflurane inhalant. A $1-\mathrm{cm}$ axillary incision allowed left lung visualization through the intercostal muscles and pleura. A549 cell suspension was injected through a 27-gauge needle into the left upper lobe at the fourth intercostal space under direct visualization. The incision was closed with 4-0 absorbable sutures, and mice were allowed to recover. Mice were arbitrarily selected and killed at 3 weeks after implantation. At necropsy, a blinded observer assessed the presence of mediastinal lymph nodes and measured tumor volume (length $\times$ width $\times$ height) with digital calipers. Tumors were either snap frozen in Tissue-Tek O.C.T. (Optimal Cutting Temperature) compound (Miles, Elkhart, Ind) in a beaker of 2-isopropanol on dry ice $\left(-18^{\circ} \mathrm{C}\right)$ or fixed in $10 \%$ neutral buffered formalin and embedded in paraffin.

Immunohistochemistry. Paraffin-embedded tissue sections were prepared on poly-L-lysine-coated slides at $4 \mu \mathrm{m}$. Sections were dewaxed in xylene and rehydrated in graded alcohol baths. Endogenous peroxidase was then blocked by means of incubation in $3 \% \mathrm{H}_{2} \mathrm{O}_{2}$ in methanol. Nonspecific mouse antigen was blocked with BEATTM blocking reagent (Zymed, South San Francisco, Calif). Primary antibody COX-2 (Cayman Chemical, Ann Arbor, Mich) was applied at 1:100 dilution in primary antibody diluting buffer (Biomedia, Foster City, Calif) at $4^{\circ} \mathrm{C}$ overnight. Detection was through a horseradish peroxidase-conjugated anti-rabbit secondary antibody (Histomouse Max Kit, Zymed) and a DAB chromagen (Zymed). Slides were counterstained with hematoxylin (Vector, Burlingame, Calif). Normal rabbit serum diluted to the same concentration as the primary and/or diluting buffer was used as a negative control. Sections of human distal vas deferens were used for positive controls. Sections were again dehydrated in graded alcohol and placed under cover slips. Images were viewed with an Olympus BX60 microscope and captured with a cooled charge-coupled device camera (Magnafire; Olympus, Melville, NY). Images were imported into Adobe Photoshop (Adobe Systems, Mountain View, Calif) as TIFF files.

Cell proliferation assays. The effect of COX-2 inhibition on A549 cell growth was determined by using a cell proliferation assay. For cell proliferation, A549 cells were seeded at a density of $5 \times 10^{3}$ per well in 96-well plates in RPMI-1640 with $10 \%$ fetal bovine serum at $37^{\circ} \mathrm{C}$. After 24 and 48 hours, fresh media with or without celecoxib in $1 \%$ dimethyl sulfoxide (DMSO) was added. At 24, 48, and 72 hours, MTS (a novel tetrazolium compound) CellTiter 96 (Promega, Madison, Wis) cell proliferation assay was performed. Viable cells convert MTS into an aqueous formazan product, which was measured on the basis of absorbance at $490 \mathrm{~nm}$.

For cell counting, A549 cells were seeded at a density of $1 \times$ $10^{6}$ cells per well in 12-well plates. Cells were treated with or without celecoxib in DMSO for 24 hours. Floating and adherent cells were combined; viable and total cell numbers were determined by use of trypan blue and a hemocytometer.

Western blot hybridization. A549 cells were seeded at a density of $1 \times 10^{6}$ cells per well in 12 -well plates with $5 \%$ fetal bovine serum and RPMI-1640 and incubated at $37^{\circ} \mathrm{C}$ overnight. Cells were then washed in PBS and subjected to the following treatments for 24 hours: media alone; $1 \%$ DMSO; $10 \mu \mathrm{mol} / \mathrm{L}$ celecoxib; interleukin (IL) $1 \beta(1 \mathrm{ng} / \mathrm{mL}$; PeproTech, Rocky Hill, $\mathrm{NJ})$; IL- $1 \beta$ plus $10 \mu \mathrm{mol} / \mathrm{L}$ celecoxib; and IL- $1 \beta$ plus $50 \mu \mathrm{mol} / \mathrm{L}$ celecoxib. IL-1 $\beta$ was used to stimulate cells to produce COX-2. Cell pellets were lysed for protein and RNA (see below). Protein assay was performed by using the Bio-Rad DC protein assay kit (Bio-Rad, Hercules, Calif). Samples were mixed with equal volumes of Tris-Glycine SDS loading buffer (Invitrogen, Carlsbad, Calif), heated at $90^{\circ} \mathrm{C}$ for 2 minutes, and loaded onto $8 \%$ to $16 \%$ Tris-Glycine gels (Invitrogen). Proteins were resolved by means of sodium dodecylsulfate-polyacrylamide gel electrophoresis $(125 \mathrm{~V}$ constant, 90 minutes, Tris-Glycine running buffer) and transferred onto polyvinylidene difluoride membranes ( $25 \mathrm{~V}$ constant, 90 minutes, Tris-Glysine transfer buffer). Membranes were washed and blocked overnight at $4{ }^{\circ} \mathrm{C}$ with $5 \%$ nonfat dry milk in Trisbuffered saline with $0.1 \%$ Tween at $\mathrm{pH}$ 7.5. Rabbit anti-human COX-2 (Cayman) at 1:1000, and $\beta$-actin at 1:800 (Santa Cruz, Santa Cruz, Calif) antibody was applied for 1 hour at $37^{\circ} \mathrm{C}$. After washing, blots were incubated with horseradish peroxidase-linked anti-rabbit IgG conjugates (Amersham Pharmacia, Arlington Heights, Ill) at 1:1000 for 1 hour at room temperature. Antibody complexes were visualized by means of enhanced chemiluminescence (Amersham). Blots were scanned with Flourochem 8900 (Alpha Innotech, San Leandro, Calif), AlphaEase imaging software (version 5.0), and Adobe Photoshop 6.0.

Reverse transcriptase polymerase chain reaction. Total RNA was extracted from A549 cells by using the RNeasy Mini-Kit (Qiagen, Valencia, Calif), and then RNA quantity and purity were confirmed spectrophotometrically. Reverse transcription was performed with the GeneAmp RNA PCR reagent kit (Applied Biosystems, Foster City, Calif). We used $1 \mu \mathrm{g}$ of RNA normalized from each sample; added $1 \mu \mathrm{L}$ of Oligo d(T) primer, $1 \mu \mathrm{L}$ of MuLV reverse transcriptase, $1 \mu \mathrm{L}$ of RNase inhibitor, $2 \mu \mathrm{L}$ of 25 


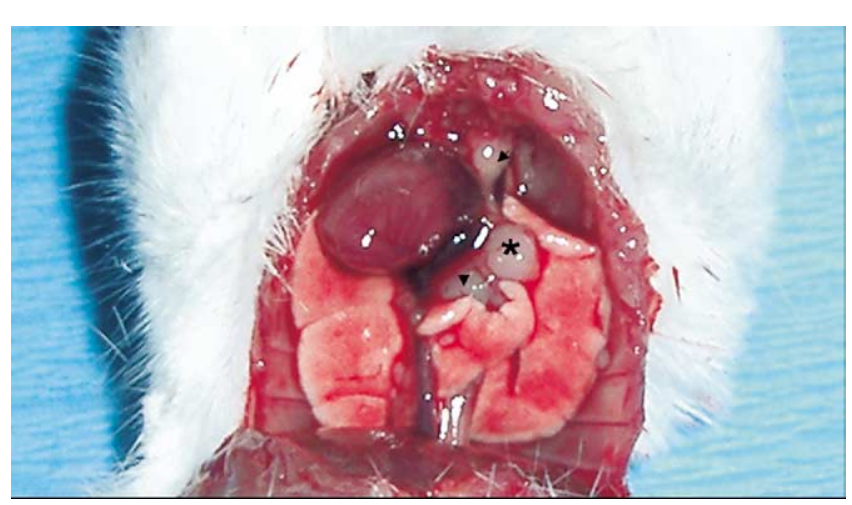

Figure 1. Mouse with severe combined immunodeficiency syndrome bearing A549 orthotopic tumor and metastases at 21 days. Asterisk, Primary tumor; arrowheads, metastases.

$\mathrm{mmol} / \mathrm{L} \mathrm{MgCl}_{2}$, deoxyribonucleoside triphosphate, and polymerase chain reaction (PCR) buffer II with a total of $20 \mu \mathrm{L}$ of reaction volume; incubated at $42^{\circ} \mathrm{C}$ for 30 minutes; heated at $99^{\circ} \mathrm{C}$ for 5 minutes; and cooled at $5^{\circ} \mathrm{C}$ for 5 minutes. Two microliters of cDNA from reverse transcription was further used for PCR amplification, with $2.5 \mu \mathrm{L}$ of $10 \times$ PCR Buffer, $2.5 \mu \mathrm{L}$ of $25 \mathrm{mmol} / \mathrm{L}$ $\mathrm{MgCl}_{2}, 2 \mu \mathrm{L}$ of $2.5 \mathrm{mmol} / \mathrm{L}$ deoxyribonucleoside triphosphate, 0.2 $\mu \mathrm{L}$ of Taq DNA polymerase, $2 \mu \mathrm{L}$ of primer, and RNase DNasefree water to a $25-\mu \mathrm{L}$ reaction volume. The following primer sequences were used: $\beta$-actin, 5'-GAG CGG GAA ATC GTG CGT GAC ATT-3' and 5'-GAT GGA GTT GAA GGT AGT TTC GTG-3' (234 bp); COX-2, 5'-TGA AAC CCA CTC CAA ACA CAG-3' and 5' -TCA TCA GGC ACA GGA GGA AG-3' (232 bp). PCR was performed (PCR Express; Thermo Hybaid, Cambridge, United Kingdom), with 35 cycles of denaturation at $94^{\circ} \mathrm{C}$ for 45 seconds, annealing at $55^{\circ} \mathrm{C}$ for 45 seconds, and extension at $72^{\circ} \mathrm{C}$ for 1 minute. PCR products $(10 \mu \mathrm{L})$ were subjected to electrophoresis on $1.5 \%$ agarose gels and visualized by means of staining with ethidium bromide.

\section{Prostaglandin $\mathbf{E}_{2}$ Levels}

Supernatant from the above experiments was collected and stored at $-70^{\circ} \mathrm{C}$. Prostaglandin $\mathrm{E}_{2}\left(\mathrm{PGE}_{2}\right)$ concentration was determined by using the Prostaglandin $\mathrm{E}_{2}$ Express ELISA immunoassay kit (Cayman) according to the manufacturer's instructions.

\section{Statistics}

Data are expressed as means \pm SD unless otherwise indicated. Differences between means for in vivo experiments were evaluated by using Welch analysis of variance (ANOVA) and ANOVA with Bonferroni post-hoc analysis. For in vitro experiments, a one-way ANOVA with Bonferroni post-test analysis was applied where appropriate.

\section{Results}

\section{Celecoxib Inhibits A549 Tumor Volume in an} Orthotopic Model

All 40 mice survived for 3 weeks without observed toxicity as manifested by weight loss or change in behavior. At 3

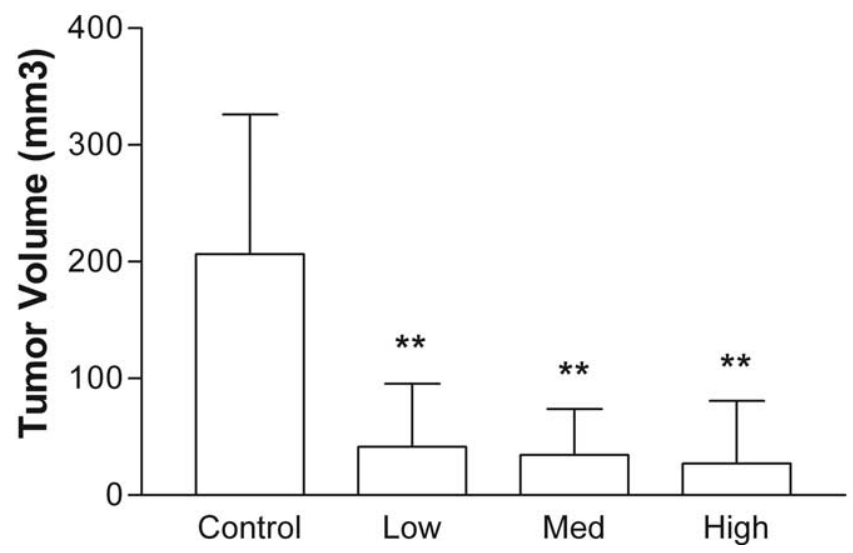

Figure 2. Orthotopic A549 versus celecoxib: absence of a dosedependent effect. Treatment with all doses of celecoxib resulted in significant inhibition of total tumor volume (in cubic millimeters). ${ }^{* *} P=.0038$, Welch ANOVA.

weeks after injection, left lung primary tumors and metastases were apparent (Figure 1). Total tumor volume was significantly inhibited in all treatment groups $(P=.0038$, Welch ANOVA), and no dose-dependent effect was evident $(P>.05$, ANOVA with Bonferroni post-hoc analysis; Figure 2). Total tumor volume was $206.7 \pm 119.5 \mathrm{~mm}^{3}$ in the control group, $41.4 \pm 54.0 \mathrm{~mm}^{3}$ in the low-dose group, 34.5 $\pm 39.3 \mathrm{~mm}^{3}$ in the medium-dose group, and $27.31 \pm 53.6$ $\mathrm{mm}^{3}$ in the high-dose group. Observed metastases were fewer in all treatment arms. The mean number of metastases was $22 \pm 15$ in the control group and $10 \pm 9.5,9.5 \pm 7.3$, and $11 \pm 9.5$ for the low-, medium-, and high-dose groups, respectively. No side effects of celecoxib were noted in any of the treatment animals.

\section{Orthotopic A549 Tumors Express COX-2}

Tumors from all treatment groups were evaluated with COX-2 immunohistochemistry. COX-2 antigen was detected in orthotopic tumors both in the untreated animals and in all treatment groups. COX-2 staining was evident in the cytoplasm and nuclei of positive cells (Figure 3).

\section{Dose-dependent Inhibition of A549 Proliferation In Vitro}

When A549 cells grown in culture were treated with increasing doses of a COX-2 inhibitor, a dose-dependent inhibition of proliferation was evident at 24, 48, and 72 hours, as demonstrated with an MTS proliferation assay (Figure 4). At doses from 5 to $25 \mu \mathrm{mol} / \mathrm{L}$ celecoxib, no significant inhibition was evident $(P>.05$, ANOVA).

\section{A549 Cells Express COX-2 and Produce PGE P $_{2}$}

A549 cells in cell culture express low levels of COX-2, as determined by means of Western blotting and reverse tran- 

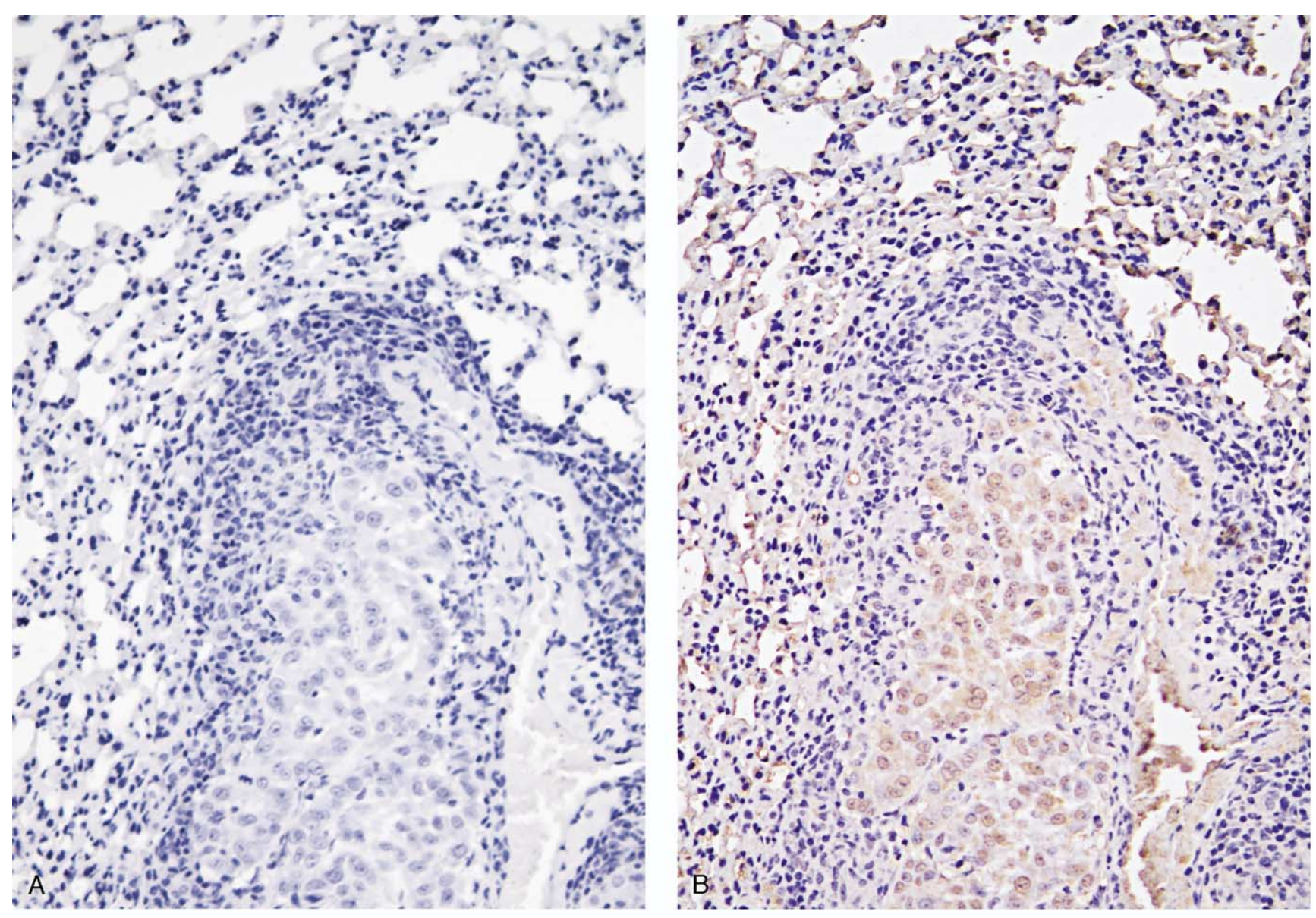

Figure 3. A, Specific COX-2 immunostaining is evident in this section of orthotopic A549 tumor. (Original magnification $100 \times$.) COX-2 is present in the cytoplasm and nucleus. Tumor sections from each treatment group demonstrate COX-2 expression. B, Negative control. (Original magnification $100 \times$.)

scription PCR. However, when A549 cells are exposed to the inflammatory cytokine IL- $1 \beta$, large amounts of COX-2 protein and mRNA are induced (Figure 5, A). A concomitant increase in $\mathrm{PGE}_{2}$ is evident in IL- $1 \beta$-stimulated cells. When treated with 10 and $50 \mu \mathrm{mol} / \mathrm{L}$ celecoxib, these stimulated cells produce little $\mathrm{PGE}_{2}$. We found these same cells to have less COX-2 mRNA than the cells stimulated with IL- $1 \beta$ alone but similar amounts of protein (Figure 5, $B$ ). In addition, there was a trend toward greater COX-2 protein expression in cells treated with IL-1 $\beta$ plus 50 $\mu \mathrm{mol} / \mathrm{L}$ celecoxib.

\section{Discussion}

The role of COX-2 in cancer has been studied extensively since epidemiologic evidence implicated aspirin and nonsteroidal anti-inflammatory drugs (NSAIDs) in improved colon carcinoma survival. ${ }^{15-17} \mathrm{COX}-2$, an inducible enzyme, is upregulated in inflammatory processes and present in many cancers; COX-1 is constitutive and responsible for cellular homeostasis in many systems. ${ }^{18}$ Both enzymes convert arachidonic acid into prostanoids. Although most NSAIDS block both COX-1 and COX-2 activity, specific COX-2 inhibitors, such as celecoxib, inhibit only the inducible isoform. This explains the improved side-effect profile of selective COX-2 inhibitors.

Several lines of in vivo evidence suggest that selective and nonselective COX-2 inhibitors can attenuate lung cancer. Aspirin, sulindac, and NS398 (a selective COX-2 inhibitor) reduced lung cancer incidence in a dose-response manner in mice exposed to tobacco-specific nitrosamine 4-(methylnitrosamino)-1-(3-pyridyl)-1-butanone. ${ }^{19,20}$ Indomethacin inhibited the accumulation of tumor cells in mouse lungs and the subsequent growth of lung metastases after intravenous injection. ${ }^{21}$ Celecoxib dose dependently inhibited primary tumor growth and the number and size of lung metastases in Lewis lung carcinoma cells and human 


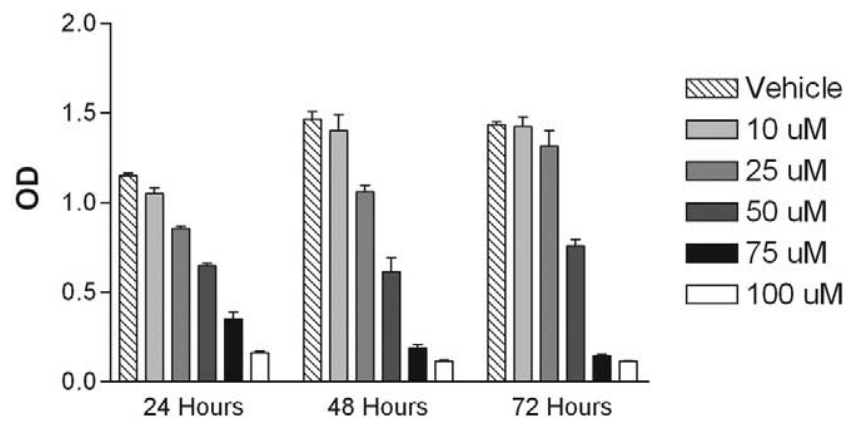

Figure 4. COX-2 inhibition of A549 cell proliferation in vitro. A549 proliferation was determined by using the MTS assay at indicated doses and shows that proliferation is only impeded at higher doses of celecoxib. Data represent 1 of 3 independent experiments done in triplicate expressed as mean \pm standard error of the mean. ${ }^{*} P<.05$ and ${ }^{* *} P<.01$, ANOVA.

colon carcinoma HT29 cells. ${ }^{12}$ Additionally, meloxicam, a preferential COX-2 inhibitor, inhibited $\mathrm{PGE}_{2}$ production and the growth of NSCLC cell lines. ${ }^{13}$

In this study an orthotopic mouse model of implanted human lung adenocarcinoma cells was used to assess the effect of 3 doses of celecoxib on tumor growth and metastasis. The A549 adenocarcinoma cell line was chosen because it is well studied and previously demonstrated inducible COX-2 expression. ${ }^{22,23}$ At 21 days after orthotopic implantation, A549 tumors are well established, most with evidence of mediastinal disease. This is consistent with our experience with another COX-2-expressing lung adenocarcinoma cell line, NCI-1975, and with that of Onn and colleagues. ${ }^{10,24}$

The celecoxib doses chosen for the in vivo study were based on the literature and previous experience. The low dose $(125 \mathrm{mg} / \mathrm{kg}$ chow, equivalent to $25 \mathrm{mg} / \mathrm{kg}$ body weight per day) was based on previously reported work that yielded celecoxib plasma levels of $0.25 \mu \mathrm{g} / \mathrm{mL}(0.6 \mu \mathrm{mol} / \mathrm{L}){ }^{10}$ These levels are similar to the $0.2 \mu \mathrm{g} / \mathrm{mL}(0.5 \mu \mathrm{mol} / \mathrm{L})$ reported by Masferrer and associates ${ }^{12}$ in their Lewis lung cancer mouse model. Similarly, the review by Davies and coworkers $^{25}$ of celecoxib pharmacokinetics reports that adults taking $800 \mathrm{mg}$ daily have plasma levels of $2.8 \mu \mathrm{g} / \mathrm{mL}$ $(7.3 \mu \mathrm{mol} / \mathrm{L})$. The plasma levels of celecoxib in the lowdose group are consequently well below the plasma levels obtained in human subjects at standard celecoxib dosing. In 2002 , Kisley and colleagues ${ }^{26}$ reported that most mice treated with $1500 \mathrm{mg} / \mathrm{kg}$ chow died, and Williams and associates $^{27}$ demonstrated a serum concentration of 2.3 $\mu \mathrm{mol} / \mathrm{L}$ in mice consuming $1250 \mathrm{mg} / \mathrm{kg}$ chow without toxicity. On the basis of these 2 studies, a high dose (1000 $\mathrm{mg} / \mathrm{kg}$ chow) was chosen to minimize toxicity and study mouse attrition.
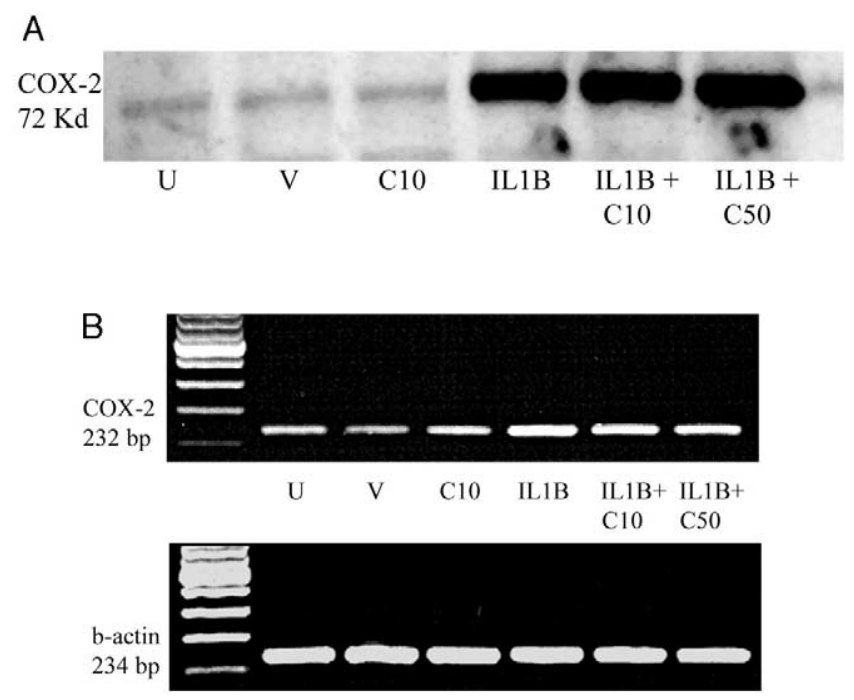

C

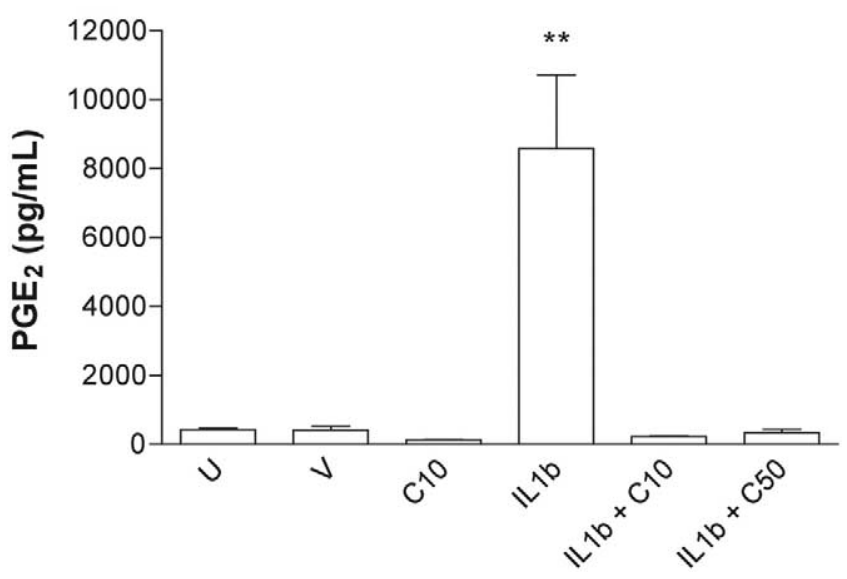

Figure 5. A, COX-2 Western blot of treated A549 cells. IL-1 $\beta$ at 1 $\mathrm{ng} / \mathrm{mL}$ stimulates the production of COX-2. Celecoxib treatment does not attenuate IL-1 $\beta$ COX-2 production. $B$, COX-2 mRNA is induced by 24 hours of IL-1 $\beta$ stimulation. Celecoxib treatment might augment the mRNA response. COX-2 and $\beta$-actin PCR products were visualized on ethidium bromide gels. $U$, Unstimulated cells; $V$, vehicle (1\% DMSO); C10, $10 \mu \mathrm{mol} / \mathrm{L}$ celecoxib; IL-1b, IL-1 $\beta$; C50, $50 \mu \mathrm{mol} / \mathrm{L}$ celecoxib. C, A549 PGE 2 level at 24 hours. IL-1 $\beta$ stimulates the production of $\mathrm{PGE}_{2}$. COX-2 enzyme activity is inhibited by 10 and $50 \mu \mathrm{mol} / \mathrm{L}$ celecoxib. Data are representative of 3 experiments and expressed as means \pm standard error of the mean.

All 3 doses of celecoxib were found to significantly reduce total tumor volume, although intergroup differences between treatment regimens were neither significant nor showed a dose-dependent response. Given the existing evidence, it was surprising to not find further attenuation of 
tumor volume with doses approaching the threshold for toxicity of this compound. Absence of a dose-dependent effect might be multifactorial, in part related to this adenocarcinoma cell line, A549, or the initiation of selective COX-2 inhibition with celecoxib at the time of tumor cell implantation. Additionally, implantation of tumor cells in lung tissue might allow crucial stromal cell and extracellular matrix interplay to develop; this could include tumorstromal cell activation of COX-2 mechanisms, where stromally derived COX-2 is important for tumor growth. ${ }^{28}$ Stromally derived processes dependent on COX-2 might be sensitive to low-dose inhibition. ${ }^{8,12,27}$

Additional in vitro studies were undertaken to further understand an absence of a dose-dependant response in vivo. A549 cells were studied with respect to the effect of selective COX-2 inhibition on cell growth, proliferation, COX-2 mRNA and protein, and the measurement of prostaglandin produced. A549 cells, when cultured, demonstrate dose-dependent COX-2 inhibition of proliferation at 24 hours. At concentrations of greater than $50 \mu \mathrm{mol} / \mathrm{L}$ celecoxib, proliferation as measured by MTS was decreased, and at concentrations of $100 \mu \mathrm{mol} / \mathrm{L}$, cell death was observed (Figure 4). An important observation from this experiment is that treatment with $10 \mu \mathrm{mol} / \mathrm{L}$ or less for 24 hours had no detrimental effect on cell proliferation. Despite this lack of effect in cultured A549 cells, we found that celecoxib strongly attenuated the growth of A549 tumors in vivo when the plasma concentration of celecoxib was approximately $1 \mu \mathrm{mol} / \mathrm{L}$. Epidemiologic studies in bladder and prostrate cancer of patients receiving long-term NSAIDs suggest an antitumor effect at doses sufficient to suppress inflammatory pain. ${ }^{29,30}$ The more recent data of chronic low-dose aspirin users further suggest that COX enzyme modulation has a chronic protective role against NSCLC. . $^{31,32}$

A549 cells in standard culture conditions have low basal levels of COX-2 mRNA and protein. It has been shown that the presence of inflammatory cytokines increases the production of COX-2 mRNA and protein (Figure 5). This response occurred in A549 cells on exposure to IL-1 $\beta$, in which an increase in COX-2 protein and $\mathrm{PGE}_{2}$ was measured after the stimulus (Figure 5). Similarly, the in vivo tumors have increased COX-2 protein, as shown with immunohistochemistry (Figure 3), and this appears to be greatest at the tumor-stromal cell interface. When celecoxib at doses of as low as $10 \mu \mathrm{mol} / \mathrm{L}$ is added to the IL- $1 \beta$ stimulated cells, production of $\mathrm{PGE}_{2}$ returned to baseline levels. This occurred despite a subjective increase in COX-2 protein levels after cytokine stimulation (Figure 5). The efficiency of the COX-2 inhibitor to block the production of prostanoids is shown by the low levels of $\mathrm{PGE}_{2}$ produced by the A549 cells when exposed to celecoxib, even after stimulation to transcribe very high quantities of $\mathrm{COX}-2$ protein.
By using $\mathrm{PGE}_{2}$ production as a surrogate for COX-2 enzyme activity, there is an expectation in vitro that a greater effect on cell proliferation would be observed at low concentrations in both the cell growth and MTS assays. The fact that there is no significant change in cell viability observed with lower concentrations of celecoxib would seem to indicate that cell death in vitro occurs through COX-2independent mechanisms and only at very high concentrations. These studies do not address the issue of whether celecoxib attenuates tumor growth in vivo through either COX-2-dependent or COX-2-independent mechanisms. However, in this orthotopic animal model, doses sufficient to block enzyme activity support, at least in part, a COX-2dependent mechanism.

In summary, inhibition of COX-2 with low-dose celecoxib restricted the growth of a lung adenocarcinoma cell line in this orthotopic mouse model. Two higher doses of celecoxib afforded no additional benefit and might be unnecessary. This study illustrates that caution must be used when attempting to extrapolate in vitro results to the context of in vivo models and human subjects, recognizing that cell culture plasma levels of a compound often far exceed what can be obtained in patients. Despite this difficulty, chronic therapy with low-dose COX-2 inhibition has the potential to interfere with disease progression in patients with NSCLC.

\section{References}

1. Vane JR, Bakhle YS, Botting RM. Cyclooxygenases 1 and 2. Ann Rev Pharmacol Toxicol. 1998;38:97-120.

2. DuBois RN, Abramson SB, Crofford L, Gupta RA, Simon LS, Van De Putte LB, et al. Cyclooxygenase in biology and disease. FASEB J. 1998;12:1063-73.

3. Mohammed SI, Bennett PF, Craig BA, Glickman NW, Mutsaers AJ, Snyder PW, et al. Effects of the cyclooxygenase inhibitor, piroxicam, on tumor response, apoptosis, and angiogenesis in a canine model of human invasive urinary bladder cancer. Cancer Res. 2002;62:356-8.

4. Soslow RA, Dannenberg AJ, Rush D, Woerner BM, Khan KN, Masferrer $\mathrm{J}$, et al. COX-2 is expressed in human pulmonary, colonic, and mammary tumors. Cancer. 2000;89:2637-45.

5. Yoshimura R, Sano H, Masuda C, Kawamura M, Tsubouchi Y, Chargui $\mathrm{J}$, et al. Expression of cyclooxygenase-2 in prostate carcinoma. Cancer. 2000;89:589-96.

6. Tsujii M, DuBois RN. Alterations in cellular adhesion and apoptosis in epithelial cells overexpressing prostaglandin endoperoxide synthase 2 . Cell. 1995;83:493-501.

7. Tsujii M, Kawano S, DuBois RN. Cyclooxygenase-2 expression in human colon cancer cells increases metastatic potential. Proc Natl Acad Sci U S A 1997;94:3336-40.

8. Tsujii M, Kawano S, Tsuji S, Sawaoka H, Hori M, DuBois RN. Cyclooxygenase regulates angiogenesis induced by colon cancer cells [published erratum appears in Cell. 1998;94:271]. Cell. 1998;93:70516.

9. Castelao JE, Bart RD III, DiPerna CA, Sievers EM, Bremner RM. Lung cancer and cyclooxygenase-2. Ann Thorac Surg. 2003;76:132735

10. DiPerna CA, Bart RD, Sievers EM, Ma Y, Starnes VA, Bremner RM. Cyclooxygenase-2 inhibition decreases primary and metastatic tumor burden in a murine model of orthotopic lung adenocarcinoma. $J$ Thorac Cardiovasc Surg. 2003;126:1129-33. 
11. Yao R, Rioux N, Castonguay A, You M. Inhibition of COX-2 and induction of apoptosis: two determinants of nonsteroidal antiinflammatory drugs' chemopreventive efficacies in mouse lung tumorigenesis. Exp Lung Res. 2000;26:731-42.

12. Masferrer JL, Leahy KM, Koki AT, Zweifel BS, Settle SL, Woerner BM, et al. Antiangiogenic and antitumor activities of cyclooxygenase-2 inhibitors. Cancer Res. 2000;60:1306-11.

13. Tsubouchi Y, Mukai S, Kawahito Y, Yamada R, Kohno M, Inoue K, et al. Meloxicam inhibits the growth of non-small cell lung cancer. Anticancer Res. 2000;20:2867-72.

14. Hida T, Kozaki K, Muramatsu H, Masuda A, Shimizu S, Mitsudomi T, et al. Cyclooxygenase-2 inhibitor induces apoptosis and enhances cytotoxicity of various anticancer agents in non-small cell lung cancer cell lines. Clin Cancer Res. 2000;6:2006-11.

15. Thun MJ, Namboodiri MM, Calle EE, Flanders WD, Heath CW Jr. Aspirin use and risk of fatal cancer. Cancer Res. 1993;53:1322-7.

16. Greenberg ER, Baron JA, Freeman DH Jr, Mandel JS, Haile R. Reduced risk of large-bowel adenomas among aspirin users. The Polyp Prevention Study Group. J Natl Cancer Inst. 1993;85:912-6.

17. Giovannucci E, Rimm EB, Stampfer MJ, Colditz GA, Ascherio A, Willett WC. Aspirin use and the risk for colorectal cancer and adenoma in male health professionals. Ann Intern Med. 1994;121:241-6.

18. Herschman HR. Primary response genes induced by growth factors and tumor promoters. Ann Rev Biochem. 1991;60:281-319.

19. Rioux N, Castonguay A. Prevention of NNK-induced lung tumorigenesis in A/J mice by acetylsalicylic acid and NS-398. Cancer Res 1998;58:5354-60.

20. Duperron C, Castonguay A. Chemopreventive efficacies of aspirin and sulindac against lung tumorigenesis in $\mathrm{A} / \mathrm{J}$ mice. Carcinogenesis. 1997; 18:1001-6

21. Levin G, Kariv N, Khomiak E, Raz A. Indomethacin inhibits the accumulation of tumor cells in mouse lungs and subsequent growth of lung metastases. Chemotherapy. 2000;46:429-37.

22. Dohadwala M, Luo J, Zhu L, Lin Y, Dougherty GJ, Sharma S, et al. Non-small cell lung cancer cyclooxygenase-2-dependent invasion is mediated by CD44. J Biol Chem. 2001;276:20809-12.

23. Croxtall JD, Flower RJ. Lipocortin 1 mediates dexamethasone-induced growth arrest of the A549 lung adenocarcinoma cell line [published erratum appears in Proc Natl Acad Sci U S A. 1992;89:8408]. Proc Natl Acad Sci U S A. 1992;89:3571-5.

24. Onn A, Isobe T, Itasaka S, Wu W, O'Reilly MS, Ki Hong W, et al. Development of an orthotopic model to study the biology and therapy of primary human lung cancer in nude mice. Clin Cancer Res. 2003; 9:5532-9.

25. Davies NM, McLachlan AJ, Day RO, Williams KM. Clinical pharmacokinetics and pharmacodynamics of celecoxib: a selective cyclo-oxygenase-2 inhibitor. Clin Pharmacokinet. 2000;38:225-42.

26. Kisley LR, Barrett BS, Dwyer-Nield LD, Bauer AK, Thompson DC, Malkinson AM. Celecoxib reduces pulmonary inflammation but not lung tumorigenesis in mice. Carcinogenesis. 2002;23:1653-60.

27. Williams CS, Watson AJ, Sheng H, Helou R, Shao J, DuBois RN. Celecoxib prevents tumor growth in vivo without toxicity to normal gut: lack of correlation between in vitro and in vivo models. Cancer Res. 2000;60:6045-51.

28. Williams CS, Tsujii M, Reese J, Dey SK, DuBois RN. Host cyclooxygenase-2 modulates carcinoma growth. J Clin Invest. 2000;105:1589-94.

29. Castelao JE, Yuan JM, Gago-Dominguez M, Yu MC, Ross RK Non-steroidal anti-inflammatory drugs and bladder cancer prevention. Br J Cancer. 2000;82:1364-9.

30. Mahmud S, Franco E, Aprikian A. Prostate cancer and use of nonsteroidal anti-inflammatory drugs: systematic review and meta-analysis Br J Cancer. 2004;90:93-9.

31. Akhmedkhanov A, Toniolo P, Zeleniuch-Jacquotte A, Koenig KL, Shore RE. Aspirin and lung cancer in women. Br J Cancer. 2002;87: 49-53.

32. Schreinemachers DM, Everson RB. Aspirin use and lung, colon, and breast cancer incidence in a prospective study. Epidemiology. 1994;5: $138-46$.

\section{Discussion}

Dr Richard Whyte (Stanford, Calif). I thought that this was a very good article that was an elegant combination of both the in vivo and in vitro model of looking at COX-2 inhibition in a lung cancer model. Although not particularly mechanistic in its construction, I think that in the beginning part of your presentation, you did talk about the potential mechanisms of action of COX-2 inhibition, namely that of inhibition of apoptosis and angiogenesis, as well as metastasis. I would urge anybody who is interested in reading more about this to go to an article that this group published in The Annals of Thoracic Surgery last year, a review article that summarizes these mechanisms elegantly, and it is well worth the read if you are interested in this.

I have 2 questions for you. The first is whether you could explain a bit more about the disparity in terms of the in vivo-in vitro models in terms of dose dependency. In the in vivo model you saw a decrease in growth of tumors at one dose but not at higher doses, whereas in the in vitro model there was more of an ongoing correlation, and I wonder why this is the case. In the in vitro model you have gradation of exposure to celecoxib. In the in vivo model you put it in the food, and I do not know whether you have any correlations between how much food these animals ingested, their plasma levels. In some models with animals, you give them a certain amount of this drug every day, whereas I do not know whether you know how much of the drug they actually got and whether that sort of confounded things slightly.

The other question I have is a more global question in terms of the epidemiology of this. It gets to the fact that some of these COX-2 inhibitors or COX inhibitors-whether it be aspirin or Celebrex or whatever, they are in such widespread use now-I wonder how it is going to be possible to determine any effect of an epidemiologic basis of these because essentially everybody takes, or at least many people take, some sort of a low-dose COX inhibitor, whether it is an aspirin a day to minimize heart attacks or whether it is Celebrex or something like that after, say, a shoulder injury while playing tennis. That sort of ubiquitous use of these drugs would make it very hard to do a study on this. I am wondering whether we should put our patients with lung cancer now on an aspirin a day just as we do to prevent heart attacks.

Dr Sievers. Thank you very much, Dr Whyte, for your kind words. I will try to answer your questions.

We like to caution against comparing both in vitro and in vivo data, despite the fact that we draw the parallels in this study. The main point of pointing out both of those drug treatments in serum levels in a dish and serum levels in the animal in the same presentation in the same article was to counteract some of the evidence that has been put out by some of our basic science colleagues in which antiapoptotic effects were demonstrated at celecoxib concentrations that are superphysiologic. Therefore although that is a problem, we wanted to highlight that we can still inhibit the tumor progression in this in vivo model at doses that are very low.

As far as how much our mice consume, this was a drug that was in the chow as opposed to gavage feeding, but over many experiments with many animals, we were able to keep track of exactly how much they ate, and our low-dose group did have blood levels that correlated with our previous experiments and with the literature. 
As far as all our patients taking the odd aspirin or Advil, that is definitely a problem, as our chemotherapy colleagues are finding out in these new prospective trials of combined therapy by adding celecoxib to standard chemotherapy regimens, but to note in the epidemiologic evidence presented with aspirin and breast cancer recently, they defined high-dose or high exposure of aspirin as taking more than 7 full-strength, 325-mg aspirins a week to count as achieving reduced risk.

Should we be taking NSAIDs to prevent cancer? Judging from our available data, we probably think that is a good idea, but again, long-term studies do need to be performed.

Dr Douglas Wood (Seattle, Wash). I offer my congratulations to you and Ross Bremner's laboratory. You are doing great work. I have a couple of questions.

First, do you have to give little doses of $\mathrm{H} 2$ antagonist to your mice to keep them from having gastric ulcers? On a more serious basis, with the new information that adjuvant chemotherapy now seems to be appropriate for even early stage resected lung cancer, will that potentially negate the potential benefit of COX-2 antagonists, or would this be given in addition to adjuvant chemotherapy? Are we at the stage where ought to go to The American College of Surgeons Oncology Group (ACOSOG) and propose a clinical trial on the basis of your work?

Dr Sievers. Thank you, Dr Wood. No, our mice did not have gastric ulcers. We did in fact look for them, and none were found in any of our experiments here or previously mentioned.

As far as combined chemotherapy or the question of adding celecoxib regimens or COX-2 inhibitory therapy to standard regimens, those are going to happen anyway. Our patients are still taking COX-2 inhibitors whether we want them to or not, and I do not think that the COX-2 inhibition by itself is going to negate any chemotherapy that is happening. In fact, we know this from some radiotherapy trials, as well as some chemotherapy trials both in animals and in early stages in human subjects. In arguments it does seem to potentiate the effect of chemotherapy. 